\title{
Asumisen valinnat
} prosessina

\section{Mervi Ilmonen}

\section{Hasu, Eija (2017). Asumisen valinnat ja päätöksenteko paljastettuina.} Aalto-yliopiston julkaisusarja. Doctoral dissertations 43/2017. Aalto ARTS Books, Helsinki.

Asumistutkijoiden kummastelun kohteena on usein suomalaisten korkea asumistyytyväisyys, joka monissa tutkimuksissa lähentelee sataa prosenttia. Tosin asumiseen ollaan tyytyväisiä monissa muissakin maissa, joten suomalaiset eivät ole tässä ihan omassa seurassaan ${ }^{1}$. Korkeaan tyytyväisyyteen ei ole oikein hyvää selitystä. Usein sellaisiksi tarjotaan rationalisointia, jonka mukaan asuminen on niin iso ja kallis päätös, että sen kritisointiin ei ole varaa perusturvallisuutta vaarantamatta, tai kompensaatiota, joka viittaa siihen, että asuminen on sittenkin vain rajallinen osa elämää, joka on vähemmän tärkeää, jos muut merkitykselliset asiat sujuvat. Asukkaiden valintojen ymmärtämiseksi tarvitaan parempia selityksiä ja pilkotumpaa tietoa asumista koskevasta päätöksenteosta, kun haluamme ymmärtää asumisen valintoja ja sitä, miten valinnat muokkaavat asumisympäristöjä ja asuntotarjontaa. Tähän Eija Hasun väitöskirja pyrkii vastaamaan tutkimuskysymyksellä, "miten asukkaat rakentavat omassa kontekstissaan asumisensa valintoja ja tekevät ne itselleen ymmärrettäviksi?"

Vastausta kysymykseen Hasu on etsinyt useissa eri tutkimushankkeissa, niistä syntyneissä kirjoituksissa ja näistä koostetuista pohdinnoista. Väitöskirja koostuu seitsemästä osin vertaisarvioidusta artikkelista² sekä suomeksi

1 Ks. esim: Jansen, Sylvia J.T. (2013). Why is Housing Always Satisfactory? A Study into the Impact of Preference and Experience on Housing Appreciation. Social Indicators Research 113:3 (2013), 785-805

2 Väitöksen jälkeen on julkaistu myös tuolloin arviointiprosessissa ollut artikkeli: Hasu, Eija (2018). Housing decisionmaking process explained by third agers, Finland: 'we didn't want this, but we chose it', Housing Studies 33:6, 837-854. 
kirjoitetusta yhteenvedosta (174 sivua). Julkaistussa väitöskirjassa artikkelit ovat näköispainoksina yhteenvedon lopuksi, joten lukijalla on mahdollisuus tutustua koko aineistoon.

Asumisen valinnoista tai asumispreferensseistä on edelleen vähänlaisesti tutkimusta, vaikka se on ollut kiinnostuksen kohteena jo parikymmentä vuotta. Eija Hasun tutkimus on tervetullut lisä sekä aihepiiriin että suomalaiseen asumisen tutkimukseen, joka on myös edelleen vähäistä. Monissa läntisissä maissa asumisen tutkimus merkityksessä Housing Studies on vakiintunut yliopistollinen tutkimusala, jossa on professuureja ja koulutusohjelmia. Suomi on eurooppalainen poikkeus, jossa ensimmäinen asumisen tutkimuksen professuuri perustettiin vasta 2005 Kuopion yliopistoon eikä määräaikaista virkaa jatkettu professori Anneli Junton kauden jälkeen. Kun asumisen tutkimusta tehdään kovin hajallaan, ei sitä koskevaa kompetenssia eikä erikoistumista ole juuri päässyt kertymään mihinkään yliopistoon. Tähän epäkohtaan toivoisi yhä parannusta.

Ympäristöministeriön ylitarkastajan Irma Uuskallion³ väitöskirja oli ensimmäisiä Suomessa julkaistuja asumisen valintoja koskevia tutkimuksia. Siinä pohdittiin Etelä-Helsingin asukkaiden valintoja ja luokiteltiin heitä erilaisiksi kuluttajatypologioiksi. Väitöskirjan aihetta vähän kummasteltiin silloin: mitä tuollaisten hyväosaisten asumisen valintojen tutkiminen hyödyttää. Tutkimusaihe oli vieras asumisen tutkimusta pitkään hallinneesta teollisen yhteiskunnan työväen asuntokysymyksen näkökulmasta, jossa asumista tarkasteltiin usein marxilaisesta tai weberiläisestä viitekehyksestä ja jossa pohdittiin paljon asumisen jakautumisen rakenteellista epäoikeudenmukaisuutta.

Jälkiteollisessa yhteiskunnassa tutkimuskohteeksi on tullut asukas ja asuminen kulutuksena. Tämä on seurausta 199o-luvun kulttuurisesta ja konstruktivistisesta käänteestä, jossa katse siirtyi rakenteista toimijoihin ja katsomosta yleisöön. Tai kuten tuolloin usein sanottiin, siirryttiin asuntopolitiikasta asumisen politiikkaan. Englanniksi tämä ilmenee housing-termin korvautumisella useissa yhteyksissä residing-käsitteellä, jolla tarkoitetaan enemmän käyttäjäkokemusta kuin perinteisempää yhteiskunnan rakenteiden tarkastelua ja asuntopolitiikan tavoitteiden määrittelyä. Asumisen tutkimuksessa erityisesti Housing Theory and Society- lehden piirissä vaikuttaneet konstruktionistit, lähinnä Jim Kemeny ja David Clapham, nostivat sosiaalisen konstruktionismin asumisen tutkimuksen teoreettiseksi viitekehykseksi. He vaativat asumisen tutkimuksen siirtymistä perinteisistä positivistisista lähestymistavoista toimijoiden asumiselle antamien merkitysten ja olemassaolevien sosiaalisten käytäntöjen tutkimukseen.

3 Uuskallio, Irma (2001). Arvostetut asuinsijat: asuinalueiden arvostuksen sosiokulttuurinen analyysi 1900-luvun Helsingissä ja Tehtaankadulta etelään. Helsingin yliopisto. Tutkimuksia / Helsingin kaupungin tietokeskus, Helsinki.) 
Hasu tunnustautuu tutkimuksessa claphamilaiseksi konstruktionistiksi ja tarkastelee tutkimuksessa ansiokkaasti ja monipuolisesti asukasta toimijana ja asumiselle annettuja merkityksiä Claphamin asumispolun hengessä4.

Tutkimuksen kiinnostava teoreettinen anti on prosessiteoria, joka haastaa preferenssiteoriaa. Preferenssiteorioiden mukaan toimijoilla ajatellaan olevan valintakriteerejä, jotka ohjaavat toimijan käyttäytymistä. Prosessiteorian mukaan preferenssit eivät hakuvaiheessa ole valmiina ja ehdottomina toimijoiden mielessä, vaan ne saattavat muuttua asunnon haun vaiheissa. Hasun prosessiteorian mukaan ehdottominakin pidetyistä valintakriteereistä ja preferoiduista asunnon ominaisuuksista saatetaan luopua ja alkuperäiset preferenssit saattavat muuttua. Asumispreferenssit eivät myöskään lopu muuttoon, vaan asumiskokemukset muuttavat preferenssejä. Asukas saattaa havaita arvokkaaksi jonkin sellaisen asumisensa ominaisuuden, jota hän ei asuntoa etsiessään osannut arvostaa. Hasu korostaa asumisen valintaa jatkuvana syklisenä prosessina, jossa asukkaat pyrkivät jatkuvasti tasapainotilaan, keinoina muuttaminen mutta myös omien tarpeiden ja toiveiden sopeuttaminen. Hasun nimeämät asumisstrategiat: optimointi, tyytyminen ja sopeutuminen tarjoavat hyvää vertailukohtaa asumispreferenssien tutkijoille.

Pidän väitöskirjassa pulmallisena sen laajuutta, joka johtaa jossain määrin rakenteellisiin ongelmiin. Kun tutkija haluaa sanoa aiheestaan kaiken, hän tulee lopulta sanoneeksi aivan liian monesta liian vähän. Pitkä yhteenveto olisi hyötynyt rajaamisesta ja syventämisestä. Vaikka tutkija tunnustautuu konstruktionistiksi, viitekehystä avataan vaatimattomasti eikä sitä kuljeteta tekstissä johdonmukaisesti. Hasun lukeneisuus on erinomaista ja aihepiirin osaaminen kiistatonta, mutta ajoittain lähteiden käyttö hämmentää, kun argumentin kuljettamisessa arvotetaan eritasoiset tekstit, kuten mielipidetekstit ja tieteellinen perustutkimus, samanarvoisiksi. Heikoimpia osuuksia tutkimuksessa on katsaus asumiskäyttäytymisen moniin näkökulmiin, jossa eri tutkimustraditioiden kontekstien ymmärrys on melko satunnaista ja ylimalkaista.

Tutkimuksen otsikkoa en pidä oikein onnistuneena, vaikka se viittaakin sekä preferenssiluokituksiin että sisältöön. Asumisen preferenssitutkimuksen merkittävä koulukunta, Delftin teknillisen yliopiston OTB ja sen tutkijat Silvia Jansen ja Henny Coolen 5 ovat vakiinnuttaneet käsitteet stated preferences (ilmaistut preferenssit) ja revealed preferences (osoitetut/todetut preferenssit) erottamaan toiveet ja toteutuneet valinnat toisistaan. Revealed preferences on kautta koko tutkimuksen käännetty paljastetuiksi preferensseiksi. Käännös

4 Clapham, David (2002). Housing Pathways: A Post Modern Analytical Framework. Housing Theory and Society June 2002. I

5 Ks. esim.: Sylvia J. T. Jansen, Henny C. C. H. Coolen and Roland W. Goetgeluk (eds): The measurement and analysis of housing preference and choice. Springer, 2011, 272 pp, ISBN 978-90-481-8893-2 
on sanatarkka eikä sille ole olemassa vakiintunutta ilmaisua, joten näin voi kääntää. Oma näkemykseni yhteiskuntatieteen roolista on hermeneuttinen, jonka mukaan yhteiskuntatieteen tulee ymmärtää ilmiöitä ja avata erilaisia tulkintoja, ei paljastaa eikä osoittaa ehdottomia totuuksia. Paljastaminen kuuluu enemmän sensaatiojournalismiin kuin tieteellisiin teksteihin, ja siksi olen omalta osaltani johdonmukaisesti käyttänyt ilmaisua todetut preferenssit.

Hasun tutkimus on kokonaisuutena erinomainen oppineisuuden osoitus ja tarpeellista luettavaa kaikille asumis- ja kaupunkitutkijoille.

Kiitän Turun yliopiston sosiologian professori Hannu Ruonavaaraa vastaväittäjän lausunnon antamisesta käyttööni. 